\title{
Regulating DNA Replication in Plants
}

\author{
Maria de la Paz Sanchez ${ }^{1,2,3}$, Celina Costas ${ }^{1,2}$, Joana Sequeira-Mendes ${ }^{1,2}$, \\ and Crisanto Gutierrez ${ }^{1}$ \\ ${ }^{1}$ Centro de Biologia Molecular "Severo Ochoa," CSIC-UAM, Nicolas Cabrera 1, Cantoblanco, \\ 28049 Madrid, Spain \\ Correspondence: cgutierrez@cbm.uam.es
}

\begin{abstract}
Chromosomal DNA replication in plants has requirements and constraints similar to those in other eukaryotes. However, some aspects are plant-specific. Studies of DNA replication control in plants, which have unique developmental strategies, can offer unparalleled opportunities of comparing regulatory processes with yeast and, particularly, metazoa to identify common trends and basic rules. In addition to the comparative molecular and biochemical studies, genomic studies in plants that started with Arabidopsis thaliana in the year 2000 have now expanded to several dozens of species. This, together with the applicability of genomic approaches and the availability of a large collection of mutants, underscores the enormous potential to study DNA replication control in a whole developing organism. Recent advances in this field with particular focus on the DNA replication proteins, the nature of replication origins and their epigenetic landscape, and the control of endoreplication will be reviewed.
\end{abstract}

Eaithful genome duplication during the $\mathrm{S}$ - phase of the cell cycle uses strategies largely conserved in all eukaryotes (DePamphilis and Bell 2011) and is pivotal to preserve genome integrity. Genome duplication in dividing plant cells has the same requirements and constraints than in animal cells, including the strict rule of occurring once and only once every cell cycle. The initial discoveries of several basic biological processes were performed in studies with plant cells, e.g., transposons, telomeres, RNA interference, to cite a few. DNA replication in eukaryotes is not an exception. Pioneering work in the mid-1950s showed the semiconservative na- ture of chromosomal DNA replication in the common bean Vicia faba (Taylor et al. 1957). Since then, plant DNA replication studies have focused primarily on defining temporal patterns of DNA replication at the chromosomal level along the $S$ phase. DNA fiber autoradiography was first used in plants to determine replicon size at the single molecule level (Nitta and $\mathrm{Na}$ gata 1976; Van't Hof 1976) and genome organization in early and late replicon families (Van't Hof et al. 1978; Van't Hof and Bjerknes 1981; reviewed in Bryant 2010; Costas et al. 2011a).

In this work, we will focus on: (1) plant DNA replication proteins (see also Supplemental

\footnotetext{
${ }^{2}$ These authors share the first authorship.

${ }^{3}$ Present address: Instituto de Ecología, Universidad Nacional Autónoma de México, 3er Circuito Exterior, Cd. Universitaria, México DF 04510, Mexico.

Editors: Stephen D. Bell, Marcel Méchali, and Melvin L. DePamphilis

Additional Perspectives on DNA Replication available at www.cshperspectives.org

Copyright (C) 2012 Cold Spring Harbor Laboratory Press; all rights reserved; doi: 10.1101/cshperspect.a010140

Cite this article as Cold Spring Harb Perspect Biol 2012;4:a010140
} 
M. de la Paz Sanchez et al.

Table 3 online); (2) plant DNA replication origins and their epigenetic landscape; (3) novel licensing mechanisms; (4) the relevance of DNA replication proteins in the control of the endoreplication cycle during plant development, and, finally; (5) a brief overview of duplication of plant DNA viruses.

\section{DNA REPLICATION PROTEINS}

\section{The Prereplication Complex}

Homologs of the major pre-RC components (ORC, CDC6, CDT1, and MCM2-7) (see Bell and Kaguni 2013) have been identified in several plant species (Gutierrez 2006; Shultz et al. 2007). Some of them, notably ORC1, CDC6, and CDT1, are encoded by duplicated genes in Arabidopsis. Although the coding regions of duplicated pre-RC proteins are largely conserved, their promoter regions differ considerably, suggesting that they are subjected to distinct transcriptional regulation.

ORC transcripts are abundant in cultured cells and in proliferating cells within the adult plant body. In addition, Arabidopsis ORC5 and ORC6 (Diaz-Trivino et al. 2005) and maize ORC3 (Witmer et al. 2003) are also expressed in nondividing cells in which they may play specific roles, still unknown, as it has been described for some metazoan ORC genes (Sasaki and Gilbert 2007). The interaction map of plant ORC subunits is also quite conserved (Witmer et al. 2003; Diaz-Trivino et al. 2005). A distinctive feature of plant ORC1 is its function as a transcriptional coactivator (Sanchez and Gutierrez 2009), contrary to the silencing role of ORC1 in yeast (Hickman and Rusche 2010). Plant ORC1 contains in its amino-terminal half a plant homeodomain (PHD) that seems to mediate interaction with trimethylated histone $\mathrm{H} 3$ at lysine $4(\mathrm{H} 3 \mathrm{~K} 4 \mathrm{me} 3)$ at the promoter of target genes (Sanchez and Gutierrez 2009). Interestingly, some of these ORC1-binding sites coincide with replication origins (Costas et al. 2011b), pointing to coordination between replication and transcription. It is worth noting that the Orc1 interaction with methylated histones also has been described in animals. Among the
ORC subunits in eukarya, only Orc1 has a BAH domain that mediates protein-protein interactions. The BAH domain in human Orc1 facilitates the ability of Orc1 to activate replication origins in vivo (Noguchi et al. 2006), and links H4K20me2 to DNA replication licensing and the Meier-Gorlin syndrome, primordial dwarfism that is related directly to mutations in prereplication proteins (Bicknell et al. 2011; Kuo et al. 2012).

Plant CDC6 and CDT1 conserve the major domains of these proteins, although each of the two homologs of CDC6 and CDT1 proteins show significant divergence, in particular CDT1 (Castellano et al. 2001, 2004). Another major difference with the metazoan proteins is the absence in plants of a homolog of metazoan geminin (Gmnn), the CDT1-interacting protein that inhibits its activity (Caro and Gutierrez 2007; Miotto and Struhl 2010). Remarkably, plants contain a completely unrelated CDT1interacting protein called GEM (GL2-EXPRESSION MODULATOR [Caro et al. 2007]). It is not known yet whether GEM has a role in DNA replication. Expression of both CDT1a and $C D T 1 b$ depends on a complex regulation. Whereas both CDT1a and CDT1b are E2F targets (Castellano et al. 2004), only CDT1a is activated by ORC1 (Sanchez and Gutierrez 2009). Both CDT1 $a$ and CDT1b genes are also repressed by ABAP1 (ARMADILLO BTB ARABIDOPSIS PROTEIN1), a novel factor that works in association with the TCP24 transcription factor (Masuda et al. 2008).

Plant MCM2-7 proteins contain the typical conserved motifs (Sabelli et al. 1996, 1999; Stevens et al. 2002; Masuda et al. 2004; Dresselhaus et al. 2006; Shultz et al. 2009). An evolutionary conserved protein called ETG1 (for E2F TARGET1) that interacts with the MCM2-7 complex has been identified in Arabidopsis (Takahashi et al. 2008). ETG1 is necessary for efficient DNA replication and its absence leads to $G_{2}$ checkpoint activation and loss of chromatid cohesion, a phenotype that is enhanced in the absence of CTF18, another factor necessary for chromatid cohesion that has been confirmed in mammalian cells (Takahashi et al. 2010). 
Replication Fork Assembly

\section{MCM8, MCM9, and MCM10}

MCM8 is highly conserved among eukaryotes, including Arabidopsis, rice, and other plants (Dresselhaus et al. 2006; Shultz et al. 2007). The major protein motifs are conserved, suggesting similar biochemical functions such as stabilization of RPA and DNA polymerase $\alpha$. However, a $\sim 60$ amino acid stretch at the amino terminus and a $\sim 20$ amino acid motif, present in animal MCM8, are missing in Arabidopsis MCM8 (Shultz et al. 2007). Their physiological relevance, if any, remains to be determined.

Genes encoding MCM9 have been identified in several plant species (Dresselhaus et al. 2006; Shultz et al. 2007) and, frequently, they are transcribed at very low levels and in different spliced forms (Schmid et al. 2005; Shultz et al. 2007). Interestingly, plant MCM9 lacks the carboxy-terminal domain present in animal MCM9, although the functional relevance of this protein organization is not known. It must be pointed out that $\mathrm{Mcm} 9$ is not essential for DNA replication in mammals, but the $\mathrm{Mcm} 8$ $\mathrm{Mcm} 9$ protein complex is involved in DNA recombination (Hartford et al. 2011; Lutzmann et al. 2012; Nishimura et al. 2012), an aspect that has not be addressed in plants.

A homolog of MCM10, a protein essential in yeast for unwinding of origin DNA and loading of DNA polymerase $\alpha$ (Kanke et al. 2012; van Deursen et al. 2012; Watase et al. 2012), has been identified in various plant species (Shultz et al. 2007). The degree of similarity is small compared with other replication proteins, although, remarkably, plant MCM10 conserves the $\mathrm{CCCH}$-type $\mathrm{Zn} 2^{+}$finger that mediates its homomultimerization.

\section{CDC45}

The function of plant CDC45 is probably to serve as a switch from the pre-RC complex to the initiation complex, because Arabidopsis CDC45 shows a $>80 \%$ similarity with $S$. pombe and human CDC45. Like in yeast and mammalian cells, Arabidopsis CDC45 gene expression is cell cycle regulated, showing high levels at the
$\mathrm{G}_{1} / \mathrm{S}$ transition (Stevens et al. 2004). In spite of these similarities, its role in plant DNA replication has not been shown. Arabidopsis CDC45 is unable to complement a yeast $c d c 45$ temperature-sensitive mutant and Arabidopsis RNAi plant lines with reduced CDC45 transcripts did not show defects in DNA synthesis (Stevens et al. 2004).

\section{GINS Complex}

The genes encoding GINS subunits have been identified in the genomic sequence of Arabidopsis, rice, maize, and soybean, including a duplicated PSF3 gene (Gutierrez 2006; Shultz et al. 2007). Interestingly, PSF2 contains a motif conserved in vertebrate but not in yeast, reinforcing the idea of a closer evolutionary relationship between Arabidopsis and human proteins. The plant GINS complex has been poorly characterized biochemically, but probably in association with MCM2-7, CDC45, and DNA polymerase $\varepsilon$, participates in initiation and fork progression, like in other eukaryotes (Gambus et al. 2006; Moyer et al. 2006).

\section{Replication Fork Progression}

\section{DNA Polymerases}

Eukaryotic DNA polymerases have been grouped in five different families, of which family B contains the replicative polymerases (Johansson and Dixon 2013). Like in animals, plant replicative DNA polymerases have been classified in three-major types: DNA polymerase $\alpha$ (POLA), DNA polymerase $\delta$ (POLD), and DNA polymerase $\varepsilon$ (POLE).

\section{POLA}

The presence of DNA polymerase $\alpha$ (POLA) activity in plants has been shown biochemically in maize, wheat, pea, and cauliflower (Bryant 1980; Castroviejo et al. 1990; Laquel et al. 1990; Balmukhanov et al. 1992; Bryant et al. 1992; Coello et al. 1992; Coello and Vazquez-Ramos 1995b; Garcia et al. 1997; Luque et al. 1998). More recently, the genome sequence analysis of Arabidopsis and 
M. de la Paz Sanchez et al.

rice allowed the identification of the four putative subunits of POLA complex (POLA1 to 4). The largest subunit (POLA1) contains the DNA polymerase activity whereas the two smallest subunits have the DNA primase activity (POLA3 and POLA4, also known as PRI1 and PRI2, respectively).

Interestingly, the POLA1 gene, also known as INCURVATA2 (ICU2), was originally identified in a genetic screen for abnormal leaf morphology and has a role in transcriptional silencing (Barrero et al. 2007; Liu et al. 2010a). The sequence features of POLA1 are conserved with the exception of a YYRRLFP motif of unknown function present in yeast and animal POLA4 subunit but not in plants (Shultz et al. 2007). Conservation of the remaining essential motifs suggests a similar function of POLA subunits in plants. In agreement with this, the plant DNA POLA complex contains a DNA polymerase activity with low processivity and a primase activity. POLA activity is regulated by phosphorylation because it increases when all subunits are phosphorylated (Coello and Vazquez-Ramos 1995a,b; Garcia et al. 1997).

\section{POLD and POLE}

Plant POLD has been described in rice, wheat, maize, and Arabidopsis (Richard et al. 1991; Garcia et al. 1997). The Arabidopsis POLD complex contains four subunits (POLD1 to D4) whereas in rice it contains five subunits (Shultz et al. 2007). Sequence analysis of Arabidopsis, soybean, rice, and maize indicated that the plant's largest subunits are highly conserved. The essential motif that mediates the interaction of POLD2 and POLD3 subunits with PCNA is conserved as well. The expression pattern of POLD1 correlates with proliferative tissues and with PCNA expression (Uchiyama et al. 2002; Garcia et al. 2006). The biochemical activity of plant DNA POLD has been assessed in wheat, and also contains an associated $3^{\prime}-5^{\prime}$ exonuclease activity, which confers a proofreading ability, and is highly stimulated by PCNA (Richard et al. 1991; Laquel et al. 1993; Luque et al. 2000). Rice POLD1 and POLD2 genes are regulated by sucrose and UV treatment
(Uchiyama et al. 2002), indicating that during evolution some replication genes have become direct targets of the environmental response.

Plant POLE has been studied in Arabidopsis and rice, including genetic analyses that have not been performed in other multicellular organisms (Jenik et al. 2005; Ronceret et al. 2005; Yin et al. 2009; del Olmo et al. 2010). Arabidopsis POLE holoenzyme possesses two catalytic subunits (POLE1A and POLE1B, also called AtPOL2a and AtPOL2b), and the regulatory subunits POLE2 (or DPB2), DPB4, and DBP3a. Genetic analysis suggests that POLE1A and/or POLE2 play a crucial role in DNA replication, whereas POLE1B is not required when POLE1A is present. In fact, the catalytic activity of POLE1A is necessary during embryogenesis, floral transition, and in meristems, whereas POLE1B is expressed at detectable levels preferentially under certain stress conditions (Jenik et al. 2005; Ronceret et al. 2005). Genes encoding the POLE3 and POLE4 subunits belong to a multigenic family and are difficult to identify unambiguously in the Arabidopsis genome. Hypomorphic mutants of POLE1 (esd7/abo4/ till) show an early flowering phenotype because of changes in the expression of key flowering genes, a process that occurs through a genetic interaction of POLE1 with LHP1 (LIKE-HETEROCHROMATIN PROTEIN1) (Yin et al. 2009; del Olmo et al. 2010).

PCNA

PCNA is an essential protein, highly conserved in all eukaryotes, including plants (Suzuka et al. 1989; Kodama et al. 1991; Hata et al. 1992; Matsumoto et al. 1994; Lopez et al. 1995; Shimizu and Mori 1998; Strzalka et al. 2010). It is frequent that plant genomes contain two PCNA genes, in contrast to PCNA pseudogenes normally found in mammalian cells. Plant PCNA forms a homotrimeric complex (Sanchez et al. 2002; Strzalka et al. 2009) that binds to various cyclin-CDK complexes (Herrera et al. 2000; Sanchez et al. 2005). In agreement with the hypothesis of serving as a sliding platform to other proteins, in vitro assays showed that PCNA-associated cyclin/CDK activity phosphorylates 
DNA polymerase $\alpha$. Because this phosphorylation does not affect DNA polymerase activity, PCNA could recruit regulatory proteins (Gomez Roig and Vazquez-Ramos 2003). Unfortunately, a direct function on the processivity and activity of the plant DNA polymerases $\delta$ or $\varepsilon$ is so far unknown. However, recombinant rice and bean PCNA stimulate human DNA polymerase $\delta$ (Matsumoto et al. 1994; Strzalka et al. 2009). In addition, two wheat DNA polymerases $\delta$ have been identified and both increase their in vitro activity and processivity when stimulated with calf thymus PCNA (Laquel et al. 1993).

The participation of plant PCNA in DNA damage processing has been shown in Arabidopsis. Thus, POLH (AtPoln) and POLL (AtPol $\lambda$ ), members of the $\mathrm{Y}$ and $\mathrm{X}$ families, respectively, interact with PCNA2 (Anderson et al. 2008; Amoroso et al. 2011) to catalyze translesion synthesis and restore replication fork progression when DNA is damaged.

\section{RFC}

All five replication factor $\mathrm{C}(\mathrm{RFC1}-5)$ subunits have been identified in plants and their sequence analysis suggests that they play roles similar to other eukaryotes (Luque et al. 2002; Furukawa et al. 2003; Shultz et al. 2007; Hedglin et al. 2013). Like other DNA replication proteins, plant $R F C$ expression occurs preferentially in proliferative tissues and is cell cycle regulated (Luque et al. 2002; Furukawa et al. 2003). RFC1 is required for replication of the ssDNAcontaining wheat dwarf virus (WDV) genome to stimulate binding of the initiator Rep protein to $3^{\prime}-\mathrm{OH}$ containing DNA substrates (Luque et al. 2002). Besides to its role as a clamp loader, RFC1 also contributes to transcriptional gene silencing of certain genes and transposons (Liu et al. 2010b).

\section{RPA}

The eukaryotic single-stranded DNA binding (SSB) protein (RPA) is required for pre- $\mathrm{RC}$ activation and for ordered loading of essential initiator factors at origins (Sakaguchi et al. 2009).
Each of the three RPA subunits is encoded by several genes in plant genomes. This allows the possibility to form different species of RPA complexes (Ishibashi et al. 2006; Shultz et al. 2007). The function of these complexes remains to be determined, but, based on their localization, one complex may act in the chloroplast, whereas other complexes could participate in nuclear processes (Ishibashi et al. 2006). Moreover, studies with mutant plants revealed that Arabidopsis RPA1A and RPA1C (nuclear proteins) are essential for DNA replication, whereas RPA1B (chloroplast and nuclear) is not essential and is required only during DNA repair (Sakaguchi et al. 2009). Apart from its function in DNA replication, RPA2 is also required to maintain transcriptional silencing of a subset of transposon elements (Elmayan et al. 2005; Kapoor et al. 2005; Xia et al. 2006).

\section{FEN1}

The specific flap endonuclease 1 (FEN1) is conserved in plants and has been characterized so far in cauliflower, wheat, rice, and Arabidopsis (Kimura et al. 1997, 2000, 2003; Przykorska et al. 2004; Shultz et al. 2007). Interestingly, Arabidopsis has only one FEN1 gene whereas rice possesses two. These are expressed in proliferating cells as well as in shoot and root apical meristems, but FEN1B is also expressed in mature organs (Kimura et al. 2000, 2003). FEN1A complements the yeast mutant strain $\Delta \mathrm{rad} 27$ (Kimura et al. 2003) and associates with PCNA, whereas FEN1B lacks a PCNA binding motif (Kimura et al. 2001), a difference that might be important for its function. The biochemical characterization of plant FEN1 indicates that this enzyme has $5^{\prime} \rightarrow 3^{\prime}$-double-strand-specific exonuclease activity and cleaves endonucleolytically at the $3^{\prime}$ end of the unpaired region in stemloop structures (Kimura et al. 1997, 2001).

\section{LIG1}

Plant DNA ligase 1 (LIG1) catalyzes the formation of a phosphodiester bond at single and double strand at various stages of DNA metabolism (Howell and Stern 1971; Kessler 1971). 
M. de la Paz Sanchez et al.

The Arabidopsis LIG1 protein can complement the $c d c 9$ temperature sensitive mutation in yeast and is expressed constitutively in all tissues analyzed (Taylor et al. 1998).

\section{DNA REPLICATION ORIGINS AND THEIR EPIGENETIC LANDSCAPE}

In eukaryotic organisms, there are thousands of sites scattered across the genome in which DNA replication begins (Méchali 2010; Leonard and Méchali 2013). However, the usage of all replication origins must be controlled by a strict regulatory mechanism to avoid genome instability. Origin specification, marked by the assembly of pre-RC in $G_{1}$, is the first level of regulation. All the potential origins that could be used during a particular S phase are licensed at this point. The second key step is origin firing, which occurs at the $G_{1} / S$ transition and during $S$ phase, and whereby only a small percentage of all the licensed origins become active. The strict regulation of the firing mechanism ensures that the replication of the DNA takes place once and only once per cell cycle (DePamphilis and Bell 2011).

The molecular mechanisms responsible for origin specification are only starting to be elucidated. In plants this issue is even more elusive and only during the last years significant advances have been made (Lee et al. 2010; Costas et al. 2011a; Liu and Gong 2011). An earlier approach consisted of scanning the ribosomal DNA (rDNA) region of cultured root meristem pea (Pisum sativum) cells to identify a replication origin within $1.5 \mathrm{~kb}$ at the nontranscribed spacer (NTS) of the rDNA (Van't Hof et al. 1987; Hernandez et al. 1993), a feature shared with other eukaryotes (DePamphilis and Bell 2011). These data were further confirmed by 2D-gel electrophoresis (Van't Hof and Lamm 1992). Recently, the development of genomic tools, including massive sequencing of newly synthesized DNA, yielded a genome-wide map of replication origins in Arabidopsis cultured cells (Costas et al. 2011b).

In multicellular organisms the DNA sequence is not sufficient for regulating the usage and function of the replication origins and other factors such as DNA methylation and epigenetic modifications of histones may play important roles (Fig. 1). The regulation and availability of the effectors of these chromatin changes (the epigenetic modifiers such as chromatin remodeling complexes, histone chaperones and histone modification enzymes) are crucial for proper DNA replication and maintenance of genome integrity. The analysis of Arabidopsis origins reveals that most of them are preferentially located at the $5^{\prime}$ ends of gene bodies and associated with highly expressed genes, as it has been described for human origins (Valenzuela et al. 2011). Additionally, they show a relatively low CG methylation whereas they are enriched in the histone variant H2A.Z (Costas et al. 2011b) and histone H3.3 (Stroud et al. 2012b). This is consistent with the depletion in CG methylation found in early and mid-S-phase replicons of Arabidopsis chromosome 4 (Lee et al. 2010). Moreover, the higher than average $C+G$ content found in Arabidopsis origin regions (midpoint $\pm 100 \mathrm{bp}$ ), associated with a low CG methylation might favor a more open chromatin that facilitates pre-RC assembly and origin activation, in agreement with results obtained in Drosophila (Macalpine et al. 2010) and mammalian cells (Karnani et al. 2010; Cayrou et al. 2011; Valenzuela et al. 2011).

The genome-wide maps of several histone modifications analyzed show that Arabidopsis origins are associated with $\mathrm{H} 3 \mathrm{~K} 4 \mathrm{me} 2, \mathrm{H} 3 \mathrm{~K} 4$ me3, and H4K5ac, and depleted of H3K4me1 and H3K9me2 (Costas et al. 2011b), a typical mark of heterochromatin in plants (Fuchs et al. 2006). Histone acetylation can affect origin specification and replication timing in other eukaryotes (Schwaiger et al. 2009; Karnani et al. 2010; Casas-Delucchi et al. 2011). In Arabidopsis, it is possible that acetylation in other histone residues, besides $\mathrm{H} 4 \mathrm{~K} 5 \mathrm{ac}$, is relevant for origin activation as suggested by the increase in histone $\mathrm{H} 3 \mathrm{~K} 18 \mathrm{ac}$ and H4K16ac observed as S phase progresses (Jasencakova et al. 2003) and by the presence of H3K56ac in early replicons (Lee et al. 2010; Roudier et al. 2011).

The observation that the Arabidopsis genome was organized in two large replicon families (Van't Hof et al. 1978), strongly suggested a temporal control of DNA replication (Jackson 


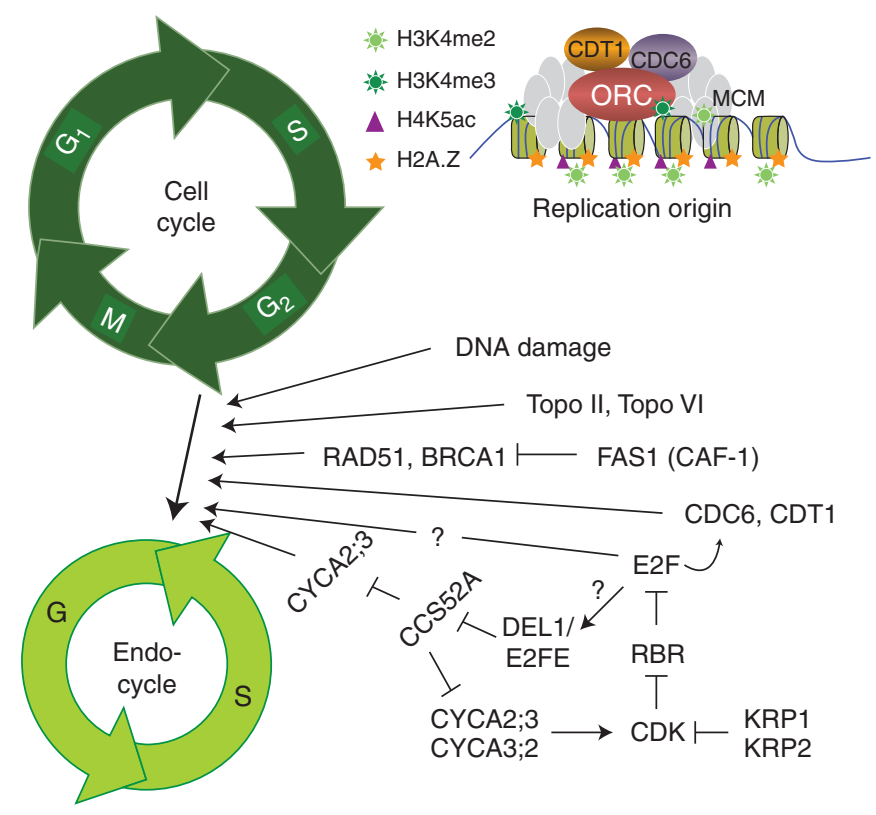

Figure 1. The transition from the cell cycle to the endoreplication cycle in plants. Replication origins during the $S$ phase of the cell cycle tend to be enriched in histone H2A.Z and some epigenetic marks, such as H3K4me2, $\mathrm{H} 3 \mathrm{~K} 4 \mathrm{me} 3$, and H4K5ac. Nucleosome occupancy across the replication origin is not considered here. Different pathways, including the direct action of replication proteins, affect the transition from the cell cycle to the endoreplication cycle. See the text for further explanation. Topo, topoisomerase.

et al. 2013). More recently, the combination of cell sorting of early, mid-, and late S-phase nuclei of culture cells with tiling microarray hybridization, revealed a biphasic mode of replication, with the majority of the euchromatin replicating in early/mid-S phase and the heterochromatin and remaining euchromatin replicating late (Lee et al. 2010). The early/mid-replicating domains colocalize with regions of open chromatin enriched in actively transcribed genes and H3K56ac. Conversely, late replicating domains are enriched in transposon elements and display repressive epigenetic marks ( $\mathrm{H} 3 \mathrm{~K} 9 \mathrm{me} 2$ and $5 \mathrm{mC}$ ). These observations are in strong agreement with the existing reports for metazoan systems (MacAlpine et al. 2004; Hiratani et al. 2009). Interestingly, H3K56ac has a fundamental role in nucleosome reassembly following DNA replication and repair (Chen and Tyler 2008) as well as in replication-independent histone turnover at promoters (Rufiange et al. 2007). However, no direct link of H3K56ac with origin activation has been provided to date.

\section{DNA REPLICATION LICENSING}

Misregulation of origin licensing has consequences on genome stability as a result of uncontrolled rereplication. Interfering with the activity of pre-RC bound to origins that have fired in a given $S$ phase is one strategy to prevent rereplication (Arias and Walter 2007). Several mechanisms, discussed elsewhere in this volume, have evolved to prevent rereplication, such as: (1) selective proteolysis of pre-RC components; (2) changes in their subcellular localization; and (3) binding of pre-RC inhibitors, such as geminin (Gmnn). Plants contain homologs of all pre-RC proteins and other factors that participate in licensing, except Gmnn (Caro and Gutierrez 2007; Shultz et al. 2007). Interestingly, they contain GEM, a CDT1-interacting protein that is structurally unrelated to metazoan Gmnn (Caro et al. 2007), but its role in licensing remains to be experimentally addressed.

Mechanistic studies of plant pre-RC dynamics are scarce. However, it is known that the 
M. de la Paz Sanchez et al.

MCM complex remains bound to chromatin throughout the cell cycle, except during mitosis (Shultz et al. 2009). Also, increased levels of CDC6 and/or CDT1 trigger extra endoreplication cycles, which implies full-genome duplication, instead of limited rereplication (Castellano et al. 2001, 2004). These differences with other model organisms support the idea that plantspecific mechanisms of rereplication control may have evolved (Costas et al. 2011a).

In addition to pre-RC availability, particular chromatin states are also involved in replication licensing control. The level of H3K27me1 is crucial to prevent rereplication in Arabidopsis heterochromatin. Thus, ATXR5 and ATXR6, encoded by E2F target genes, are monomethyl H3K27 transferases that interact with PCNA (Raynaud et al. 2006; Jacob et al. 2009). Massive sequencing of sorted $2-16 \mathrm{C}$ nuclei of an atxr5 atxr6 double mutant revealed, surprisingly, a significant increase $(>30 \%)$ in the amount of pericentromeric heterochromatic sequences (Jacob et al. 2010). In fact, the PCNA-interacting protein (PIP) motif of ATXR5 and ATXR6 is required to prevent the rereplication phenotype (Jacob et al. 2010). Moreover, the rereplicated sequences are preferentially located at specific loci, suggesting a heterochromatin-specific loss of licensing control, although dispersed heterochromatic regions across chromosome arms also show rereplicated material. Furthermore, the rereplication phenotype of atxr 5 atxr6 mutants requires factors involved in DNA methylation, as revealed by the reduced rereplication observed in $d d m 1$, met 1 and, to a lesser extent, cmt3 DNA methylation mutant backgrounds (Stroud et al. 2012a), although H3K27mel is not affected by the DNA methylation level (Mathieu et al. 2005). It is worth noting that a heterochromatin-specific rereplication control depends on geminin in Drosophila (Ding and MacAlpine 2010). In animal cells, the level of $\mathrm{H} 4 \mathrm{~K} 20 \mathrm{me} 1$ is crucial to restrain rereplication (Tardat et al. 2010). The existence of H4K20 methylation in plants has not been shown yet by mass spectrometry (Zhang et al. 2007). However, immunofluorescence and ChIP experiments show important differences with animal cells, because H4K20me1 is typical of pericen- tromeric heterochromatin whereas H4K20me3 associates with active euchromatic promoters (Fischer et al. 2006; Fuchs et al. 2006). In fact, $\mathrm{H} 4 \mathrm{~K} 20 \mathrm{me} 3$ colocalizes with a subset of ORC1binding sites, some of which act as replication origins (Sanchez and Gutierrez 2009).

\section{DNA REPLICATION AND ENDOREPLICATION DURING DEVELOPMENT}

One characteristic feature of plant development is that organogenesis is an indeterminate and postembryonic process that occurs continuously during the life of the adult plant (Gutierrez 2005; Inze and De Veylder 2006). This growth pattern implies a high coordination to maintain the balance between pools of proliferating and arrested cells that eventually initiate differentiation and organ formation. In response to certain developmental cues, as well as to environmental factors, proliferating cells exit the cell cycle to enter the endocycle, whereby full genome duplication occurs several times in the absence of an intervening mitosis (Caro et al. 2008; Breuer et al. 2010; De Veylder et al. 2011). Endoreplication is a prerequisite for certain differentiation pathways and is regulated at the level of initiation, maintenance and number of replication rounds to be developed. It must be emphasized that endoreplication is not equivalent to a loss of the licensing control (Zielke et al. 2013), because it involves duplication of the entire genome during each endoreplication cycle instead of uncontrolled reinitiation events within a genomic locus.

As in the case of metazoa, endocycling in plant cells faces the challenge of maintaining CDK activity sufficiently below a threshold to prevent triggering of mitosis. This is achieved by controlling the levels of CDK activity through regulating the amount of $\mathrm{CDK}$ (protein and activity), the availability of cyclins, and the levels of CDK inhibitors (De Veylder et al. 2011). Thus, several mechanisms have evolved, in some cases independently of those acting in metazoa. It must be kept in mind that plants contain several non-PSTAIRE CDK involved in cell cycle progression and a large set of cyclins of the A-, 
B-, and D types, but they lack a typical E-type cyclin (Gutierrez 2009).

The APC/C degrades several cyclins including CYCB1;1, CYCB1;2, CYCA2;3, and CYCA3;1 (De Veylder et al. 2011). In Arabidopsis, homologs of both Cdc20/Fzy and Cdh1/Fzr APC/C activators exist and participate in controlling the onset of endocycles by targeting various cyclins (Gutierrez 2009). The Arabidopsis homolog of Cdh1/Fzr is known as CCS52A (CELL CYCLE SWITCH 52A), and its loss of function produces a reduction in ploidy (Cebolla et al. 1999; Larson-Rabin et al. 2009). Interestingly, CCS52A is a target of E2FE/DEL1, one of the three atypical E2F encoded in the Arabidopsis genome (Ramirez-Parra et al. 2007; Lammens et al. 2008) and homolog of the human E2F7-9. Thus, the availability of APC/C activators is crucial for the endocycle switch. This is controlled in Arabidopsis by the UVI4 and GIG1/OSD1 (GIGAS CELLS 1/OMISSION OF SECOND DIVISION 1) proteins that interfere with the activity of the CDC20/FZY and CCS52A activators, respectively (Iwata et al. 2011). Remarkably, altering GIG1/OSD1 function increases ploidy through endomitosis whereas in the case of UVI4 is typically though endoreplication. CYCA2;3 levels are independently regulated by various proteins, such as ILP1 (Yoshizumi et al. 2006), a homolog of the mammalian GC-binding protein, and TCP15, a transcription factor that induces extra endocycles when it is overexpressed in cells genetically programmed to endoreplicate ( $\mathrm{Li}$ et al. 2012).

Reduced activity of CDKB1;1, a non-PSTAIRE plant-specific CDK partner of CYCA2;3, increases endoreplication (Boudolf et al. 2009). CDKB1;1/CYCA2;3 activity is also required to phosphorylate several MYB transcription factors that activate the expression of $\mathrm{G}_{2} / \mathrm{M}$-specific genes (Araki et al. 2004; Kato et al. 2009). Plants contain two major classes of CDK inhibitors. One includes proteins with a domain conserved in animal p27 and is known as the KRP family, which in Arabidopsis contains seven members (Gutierrez 2009). The other is a plantspecific class constituted by SIAMESE (SIM) and SIM-RELATED (SMR) inhibitors (Walker et al. 2000; Churchman et al. 2006). Overexpres- sion of KRP1/ICK1 and KRP2/ICK2, which are preferentially expressed in endoreplicating cells, affects the switch to endocycles in Arabidopsis (Wang et al. 2000; De Veylder et al. 2001; Verkest et al. 2005; Weinl et al. 2005), maize (Coelho et al. 2005), and tomato (Bisbis et al. 2006), whereas endoreplication is repressed in the sim mutants (Churchman et al. 2006). Interestingly, SIM interacts with the CDKA; 1 , the canonical PSTAIRE-type CDK, and with cyclin D, implicating this cyclin not only in the $\mathrm{G}_{1} / \mathrm{S}$ transition but also in control of endocycles. Consistent with this, CYCD3 overexpression induces hyperplasia and reduction of the number of endoreplicated cells in various Arabidopsis organs (Dewitte et al. 2003) whereas a triple $c y c d 3 ; 1$ 2-3 mutant contains reduced cell number and increased endoreplication levels (Dewitte et al. 2007). CDKA/CYCD3 are responsible for the phosphorylation of RBR (RETINOBLASTOMARELATED), the homolog of the mammalian $\mathrm{RB}$ protein. In fact, the RBR pathway regulates the number of endocycles once cells have exited the cell cycle (Park et al. 2005; Desvoyes et al. 2006; Borghi et al. 2010). Whether it is a direct effect or mediated by downstream RBR/E2F targets is not clear. For example, maintaining high levels of CDC6 and/or CDT1, which are regulated by RBR/E2F, during leaf development increases cellular ploidy (Castellano et al. 2001, 2004). Together, these data show a direct role of RBR/E2F, some of their targets, and CDK/cyclin in controlling endoreplication during development.

Several topoisomerases are also crucial for the endoreplication cycles (Fig. 1). Thus, mutations in the $\mathrm{A}$ and $\mathrm{B}$ subunits of topoisomerase VI, encoded by the ROOT HAIRLESS2 (RHL2) and HYPOCOTYL6 (HYP6) genes, prevent endocycle progression beyond the 8C DNA level (Hartung et al. 2002; Sugimoto-Shirasu et al. 2002). Likewise, cells of the root hairless1/ hypocotyl7 mutant that lack topoisomerase II show abnormal endocycle progression (SugimotoShirasu et al. 2005). Therefore, functional topoisomerases are not needed for initiation of the endoreplication program, but they are at later stages, likely to handle topological constraints produced when the ploidy level increases. A 
M. de la Paz Sanchez et al.

systematic evaluation of the possible role of other DNA replication factors in endoreplication control would be enlightening.

A correct DNA replication-dependent deposition of histones $\mathrm{H} 3$ and $\mathrm{H} 4$ is required in Arabidopsis to prevent activation of the $\mathrm{G}_{2}$ checkpoint (Fig. 1). Mutants in the FASCIATA1 (FAS1) gene, encoding the large subunit of the $\mathrm{H} 3-\mathrm{H} 4$ chaperone chromatin assembly factor 1 (CAF1 ), show a constitutive activation of the $G_{2}$ checkpoint, including transcriptional activation of RAD51 and BRCA1 genes, among others (Ramirez-Parra and Gutierrez 2007a). Mutant cells, instead of becoming permanently arrested or forced to enter a death pathway, trigger the endoreplication program ectopically and at developmental times in which it should not occur. It has been speculated that plants have evolved the ability to switch to the endocycle as a way to escape permanent cell cycle arrest during development (Ramirez-Parra and Gutierrez 2007b).

Although the endoreplication field is advancing quickly several key questions still remain unanswered. These include: (1) how licensing occurs in the absence of mitosis; (2) what is the replication timing and origin usage in relation to the $S$ phase of the cell cycle; (3) what are the origins active in each endoreplication round and whether they are the same as those used during the cell cycle. Because the experimental approaches are now available, it is likely that studies in whole plants will contribute to significant advances in the coming years.

\section{GEMINIVIRUS DNA REPLICATION}

Geminiviruses are a family of plant viruses that have a significant impact in agricultural production worldwide. Their genome consists of 1 or 2 molecules of single-stranded DNA (ssDNA), $\sim 2.4-3.1 \mathrm{~kb}$ in length, depending on the virus genera (Mastre-, Curto-, Topocu-, and Begomovirus). A comprehensive review of geminivirus biology has appeared recently (Jeske 2009). Others have covered aspects more related to DNA replication (Hanley-Bowdoin et al. 2004; Gutierrez 2006; Ascencio-Ibanez et al. 2008).

The replication cycle includes a first stage in which ssDNA is converted into dsDNA, a pro- cess performed entirely by host proteins. The dsDNA is used as a substrate in which 1316 superhelical turns are introduced by association with histone octamers (Pilartz and Jeske 1992), much in the same way as it occurs with SV40 DNA. In the second stage, new viral ssDNA molecules are produced by a rollingcircle mechanism (Gutierrez 1999; Saunders 2008). The viral initiator protein (Rep) is a multifunctional protein with origin-specific DNA binding, homo- and heteroligomerization, and helicase and endonuclease activities (reviewed in Jeske 2009). Interestingly, Rep-binding sites at the replication origin are located in close proximity or partially overlapping the two divergent promoters responsible for early and late viral gene expression (reviewed in Gutierrez 2002). In addition to the rolling-circle replication pathway, a recombination-dependent replication mechanism that does not rely on a sequence-specific replication origin is also used (Jeske 2009).

A rich variety of interactions of viral early proteins with host factors have been identified as necessary for efficient viral DNA replication. These include: (1) inactivation of the retinoblastoma-related pathway (Xie et al. 1995; Kong et al. 2000), the $\mathrm{G}_{2} / \mathrm{M}$ transition (Kong and HanleyBowdoin 2002; Nagar et al. 2002), and the host antiviral defense and silencing mechanisms ( Vanitharani et al. 2005); (2) interaction with cell differentiation transcription factors (Xie et al. 1999; Selth et al. 2005), pathogen response (Ascencio-Ibanez et al. 2008), the ubiquitination (Lai et al. 2009; Zhang et al. 2011), and the sumoylation system (Castillo et al. 2004; SanchezDuran et al. 2011); and (3) recruitment of DNA replication factors such as RFC1 (Luque et al. 2002), PCNA (Castillo et al. 2003), RPA2 (Singh et al. 2007), and POLA2 and POLD2 (LozanoDuran et al. 2011).

\section{ACKNOWLEDGMENTS}

We are indebted to the C.G. laboratory members for insightful discussions. C.C. and J.S.-M. are recipients of JAE-Doc (CSIC) and Juan de la Cierva (MICINN) contracts, respectively. Research is supported by grants BFU2009-9783 
and CSD2007-00057-B (Ministry of Science and Education), and by an institutional grant from Fundación Ramón Areces.

\section{REFERENCES}

* Reference is also in this collection.

Amoroso A, Concia L, Maggio C, Raynaud C, Bergounioux C, Crespan E, Cella R, Maga G. 2011. Oxidative DNA damage bypass in Arabidopsis thaliana requires DNA polymerase lambda and proliferating cell nuclear antigen 2. Plant Cell 23: 806-822.

Anderson HJ, Vonarx EJ, Pastushok L, Nakagawa M, Katafuchi A, Gruz P, Di Rubbo A, Grice DM, Osmond MJ, Sakamoto AN, et al. 2008. Arabidopsis thaliana Y-family DNA polymerase eta catalyses translesion synthesis and interacts functionally with PCNA2. Plant J 55: 895-908.

Araki S, Ito M, Soyano T, Nishihama R, Machida Y. 2004. Mitotic cyclins stimulate the activity of c-Myb-like factors for transactivation of $\mathrm{G} 2 / \mathrm{M}$ phase-specific genes in tobacco. J Biol Chem 279: 32979-32988.

Arias EE, Walter JC. 2007. Strength in numbers: Preventing rereplication via multiple mechanisms in eukaryotic cells. Genes Dev 21: 497-518.

Ascencio-Ibanez JT, Sozzani R, Lee TJ, Chu TM, Wolfinger RD, Cella R, Hanley-Bowdoin L. 2008. Global analysis of Arabidopsis gene expression uncovers a complex array of changes impacting pathogen response and cell cycle during geminivirus infection. Plant Physiol 148: 436-454.

Balmukhanov TS, Erekenov AM, Ajtkhozhina NA. 1992. Isolation of DNA polymerase $\alpha$ from germinated wheat embryos. Mol Biol Rep 16: 11-16.

Barrero JM, Gonzalez-Bayon R, del Pozo JC, Ponce MR, Micol JL. 2007. INCURVATA2 encodes the catalytic subunit of DNA Polymerase $\alpha$ and interacts with genes involved in chromatin-mediated cellular memory in Arabidopsis thaliana. Plant Cell 19: 2822-2838.

* Bell SP, Kaguni JM. 2013. Helicase loading at chromosomal origins of replication. Cold Spring Harb Perspect Biol doi: 10.1101/cshperspect.a010124.

Bicknell LS, Walker S, Klingseisen A, Stiff T, Leitch A, Kerzendorfer C, Martin CA, Yeyati P, Al Sanna N, Bober M, et al. 2011. Mutations in ORC1, encoding the largest subunit of the origin recognition complex, cause microcephalic primordial dwarfism resembling MeierGorlin syndrome. Nature Genet 43: 350-355.

Bisbis B, Delmas F, Joubes J, Sicard A, Hernould M, Inze D, Mouras A, Chevalier C. 2006. Cyclin-dependent kinase (CDK) inhibitors regulate the CDK-cyclin complex activities in endoreduplicating cells of developing tomato fruit. J Biol Chem 281: 7374-7383.

Borghi L, Gutzat R, Futterer J, Laizet Y, Hennig L, Gruissem W. 2010. Arabidopsis RETINOBLASTOMA-RELATED is required for stem cell maintenance, cell differentiation, and lateral organ production. Plant Cell 22: 1792-1811.

Boudolf V, Lammens T, Boruc J, Van Leene J, Van Den Daele H, Maes S, Van Isterdael G, Russinova E,
Kondorosi E, Witters E, et al. 2009. CDKB1;1 forms a functional complex with CYCA2;3 to suppress endocycle onset. Plant Physiol 150: 1482-1493.

Breuer C, Ishida T, Sugimoto K. 2010. Developmental control of endocycles and cell growth in plants. Curr Opin Plant Biol 13: 654-660.

Bryant JA. 1980. Biochemical aspects of DNA replication with particular reference to plants. Biol Rev Camb Philos Soc 55: 237-284.

Bryant JA. 2010. Replication of nuclear DNA. Prog Bot 71: 25-60.

Bryant J, Fitchett P, Hughes S, Sibson D. 1992. DNA polymerase a in pea is part of a large multiprotein complex. $J$ Exp Bot 43: 31-40.

Caro E, Gutierrez C. 2007. A green GEM: Intriguing analogies with animal geminin. Trends Cell Biol 17: 580-585.

Caro E, Castellano MM, Gutierrez C. 2007. A chromatin link that couples cell division to root epidermis patterning in Arabidopsis. Nature 447: 213-217.

Caro E, Desvoyes B, Ramirez-Parra E, Sanchez Mde L, Gutierrez C. 2008. Endoreduplication control during plant development. SEB Exp Biol Ser 59: 167-187.

Casas-Delucchi CS, van Bemmel JG, Haase S, Herce HD, Nowak D, Meilinger D, Stear JH, Leonhardt H, Cardoso MC. 2011. Histone hypoacetylation is required to maintain late replication timing of constitutive heterochromatin. Nucleic Acids Res doi: 10.1093/nar/gkr723.

Castellano MM, del Pozo JC, Ramirez-Parra E, Brown S, Gutierrez C. 2001. Expression and stability of Arabidopsis CDC6 are associated with endoreplication. Plant Cell 13: 2671-2686.

Castellano MM, Boniotti MB, Caro E, Schnittger A, Gutierrez C. 2004. DNA replication licensing affects cell proliferation or endoreplication in a cell type-specific manner. Plant Cell 16: 2380-2393.

Castillo AG, Collinet D, Deret S, Kashoggi A, Bejarano ER. 2003. Dual interaction of plant PCNA with geminivirus replication accessory protein (Ren) and viral replication protein (Rep). Virology 312: 381-394.

Castillo AG, Kong LJ, Hanley-Bowdoin L, Bejarano ER. 2004. Interaction between a geminivirus replication protein and the plant sumoylation system. J Virol 78: 27582769.

Castroviejo M, Gatius MT, Litvak S. 1990. A low molecular weight DNA polymerase from wheat embryos. Plant Mol Biol 15: 383-397.

Cayrou C, Coulombe P, Vigneron A, Stanojcic S, Ganier O, Peiffer I, Rivals E, Puy A, Laurent-Chabalier S, Desprat R, et al. 2011. Genome-scale analysis of metazoan replication origins reveals their organization in specific but flexible sites defined by conserved features. Genome Res 21: 1438-1449.

Cebolla A, Vinardell JM, Kiss E, Olah B, Roudier F, Kondorosi A, Kondorosi E. 1999. The mitotic inhibitor ccs52 is required for endoreduplication and ploidy-dependent cell enlargement in plants. EMBO J 18: 4476-4484.

Chen CC, Tyler J. 2008. Chromatin reassembly signals the end of DNA repair. Cell Cycle 7: 3792-3797.

Churchman ML, Brown ML, Kato N, Kirik V, Hulskamp M, Inze D, De Veylder L, Walker JD, Zheng Z, Oppenheimer DG, et al. 2006. SIAMESE, a plant-specific cell 
M. de la Paz Sanchez et al.

cycle regulator, controls endoreplication onset in Arabidopsis thaliana. Plant Cell 18: 3145-3157.

Coello P, Vazquez-Ramos JM. 1995a. Maize DNA polymerase 2 is a phosphoprotein with increasing activity during germination. Eur J Biochem 231: 99-103.

Coello P, Vazquez-Ramos JM. 1995b. Studies on the processivity of maize DNA polymerase 2 , an $[\alpha]$-type enzyme. Plant Physiol 109: 645-650.

Coello P, Rodriquez R, Garcia E, Vazquez-Ramos JM. 1992. A DNA polymerase from maize axes: its purification and possible role. Plant Mol Biol 20: 1159-1168.

Coelho CM, Dante RA, Sabelli PA, Sun Y, Dilkes BP, Gordon-Kamm WJ, Larkins BA. 2005. Cyclin-dependent kinase inhibitors in maize endosperm and their potential role in endoreduplication. Plant Physiol 138: 2323-2336.

Costas C, Sanchez MP, Sequeira-Mendes J, Gutierrez C. 2011a. Progress in understanding DNA replication control. Plant Scie (Shannon, Ireland) 181: 203-209.

Costas C, Sanchez MP, Stroud H, Yu Y, Oliveros JC, Feng S, Benguria A, Lopez-Vidriero I, Zhang X, Solano R, et al. 2011b. Genome-wide mapping of Arabidopsis origins of DNA replication and their associated epigenetic marks. Nat Struct Mol Biol 18: 395-400.

De Veylder L, Beemster GT, Beeckman T, Inze D. 2001. CKS1At overexpression in Arabidopsis thaliana inhibits growth by reducing meristem size and inhibiting cellcycle progression. Plant J 25: 617-626.

De Veylder L, Larkin JC, Schnittger A. 2011. Molecular control and function of endoreplication in development and physiology. Trends Plant Sci 16: 624-634.

del Olmo I, Lopez-Gonzalez L, Martin-Trillo MM, Martinez-Zapater JM, Pineiro M, Jarillo JA. 2010. EARLY IN SHORT DAYS 7 (ESD7) encodes the catalytic subunit of DNA polymerase epsilon and is required for flowering repression through a mechanism involving epigenetic gene silencing. Plant J 61: 623-636.

DePamphilis M, Bell S. 2011. Genome duplication. Concepts, mechanisms, evolution, and disease. Garland Science, Taylor \& Francis Group London.

Desvoyes B, Ramirez-Parra E, Xie Q, Chua NH, Gutierrez C. 2006. Cell type-specific role of the retinoblastoma/E2F pathway during Arabidopsis leaf development. Plant Physiol 140: 67-80.

Dewitte W, Riou-Khamlichi C, Scofield S, Healy JM, Jacqmard A, Kilby NJ, Murray JA. 2003. Altered cell cycle distribution, hyperplasia, and inhibited differentiation in Arabidopsis caused by the D-type cyclin CYCD3. Plant Cell 15: 79-92.

Dewitte W, Scofield S, Alcasabas AA, Maughan SC, Menges M, Braun N, Collins C, Nieuwland J, Prinsen E, Sundaresan V, et al. 2007. Arabidopsis CYCD3 D-type cyclins link cell proliferation and endocycles and are rate-limiting for cytokinin responses. Proc Natl Acad Sci 104: 14537-14542.

Diaz-Trivino S, Castellano MM, Sanchez MP, RamirezParra E, Desvoyes B, Gutierrez C. 2005. The genes encoding Arabidopsis ORC subunits are E2F targets and the two ORC1 genes are differently expressed in proliferating and endoreplicating cells. Nucleic Acids Res 33: 5404-5414.
Ding Q, MacAlpine DM. 2010. Preferential re-replication of Drosophila heterochromatin in the absence of geminin. PLoS Genet 6: e1001112.

Dresselhaus T, Srilunchang KO, Leljak-Levanic D, Schreiber DN, Garg P. 2006. The fertilization-induced DNA replication factor MCM6 of maize shuttles between cytoplasm and nucleus, and is essential for plant growth and development. Plant Physiol 140: 512-527.

Elmayan T, Proux F, Vaucheret H. 2005. Arabidopsis RPA2: A genetic link among transcriptional gene silencing, DNA repair, and DNA replication. Curr Biol 15: 1919-1925.

Fischer A, Hofmann I, Naumann K, Reuter G. 2006. Heterochromatin proteins and the control of heterochromatic gene silencing in Arabidopsis. J Plant Physiol 163: $358-$ 368.

Fuchs J, Demidov D, Houben A, Schubert I. 2006. Chromosomal histone modification patterns-from conservation to diversity. Trends Plant Sci 11: 199-208.

Furukawa T, Ishibashi T, Kimura S, Tanaka H, Hashimoto J, Sakaguchi K. 2003. Characterization of all the subunits of replication factor C from a higher plant, rice (Oryza sativa L.), and their relation to development. Plant Mol Biol 53: 15-25.

Gambus A, Jones RC, Sanchez-Diaz A, Kanemaki M, van Deursen F, Edmondson RD, Labib K. 2006. GINS maintains association of Cdc45 with MCM in replisome progression complexes at eukaryotic DNA replication forks. Nat Cell Biol 8: 358-366.

Garcia E, Orjuela D, Camacho Y, Zuniga JJ, Plasencia J, Vazquez-Ramos JM. 1997. Comparison among DNA polymerases 1, 2 and 3 from maize embryo axes. A DNA primase activity copurifies with DNA polymerase 2 . Plant Mol Biol 33: 445-455.

Garcia E, Quiroz F, Uchiyama Y, Sakaguchi K, VazquezRamos JM. 2006. Expression of a maize $\delta$-type DNA polymerase during seed germination. Physiol Plant 127: $268-276$.

Gomez Roig E, Vazquez-Ramos JM. 2003. Maize DNA polymerase $\alpha$ is phosphorylated by a PCNA-associated cyclin/Cdk complex: Effect of benzyladenine. J Plant Physiol 160: 983-990.

Gutierrez C. 1999. Geminivirus DNA replication. Cell Mol Life Sci 56: 313-329.

Gutierrez C. 2002. Strategies for geminivirus DNA replication and cell cycle interference. Physiol Plant Mol Biol 69: 219-230.

Gutierrez C. 2005. Coupling cell proliferation and development in plants. Nat Cell Biol 7: 535-541.

Gutierrez C. 2006. Plant cell and viruses. In DNA replication and human disease (ed. DePamphilis ML), pp. 257-271. Cold Spring Harbor Laboratory Press, Cold Spring Harbor, NY.

Gutierrez C. 2009. The Arabidopsis cell cycle. In The arabidopsis book. ASPB, http://www.aspb.org/publications/ arabidopsis/.

Hanley-Bowdoin L, Settlage SB, Robertson D. 2004. Reprogramming plant gene expression: A prerequisite to geminivirus DNA replication. Mol Plant Pathol 5: 149-156.

Hartford SA, Luo Y, Southard TL, Min IM, Lis JT, Schimenti JC. 2011. Minichromosome maintenance helicase paralog MCM9 is dispensable for DNA replication but 
functions in germ-line stem cells and tumor suppression. Proc Natl Acad Sci 108: 17702-17707.

Hartung F, Angelis KJ, Meister A, Schubert I, Melzer M, Puchta H. 2002. An archaebacterial topoisomerase homolog not present in other eukaryotes is indispensable for cell proliferation of plants. Curr Biol 12: 1787-1791.

Hata S, Tsukamoto T, Osumi T, Hashimoto J, Suzuka I. 1992. Analysis of carrot genes for proliferating cell nuclear antigen homologs with the aid of the polymerase chain reaction. Biochem Biophys Res Commun 184: 576-581.

* Hedglin M, Kumar R, Benkovic SJ. 2013. Replication clamps and clamp loaders. Cold Spring Harb Perspect Biol doi: 10.1101/cshperspect.a010165.

Hernandez P, Martin-Parras L, Martinez-Robles ML, Schvartzman JB. 1993. Conserved features in the mode of replication of eukaryotic ribosomal RNA genes. $E M B O$ J 12: $1475-1485$.

Herrera I, Sánchez MP, Molina J, Plasencia J, VázquezRamos J. 2000. Proliferating cell nuclear antigen expression in maize seed development and germination: Regulation by phytohormones and its association with putative cell cycle proteins. Physiol Plant 110: 127-134.

Hickman MA, Rusche LN. 2010. Transcriptional silencing functions of the yeast protein Orc1/Sir3 subfunctionalized after gene duplication. Proc Natl Acad Sci 107: 19384-19389.

Hiratani I, Takebayashi S, Lu J, Gilbert DM. 2009. Replication timing and transcriptional control: Beyond cause and effect-part II. Curr Opin Genet Dev 19: 142-149.

Howell SH, Stern H. 1971. The appearance of DNA breakage and repair activities in the synchronous meiotic cycle of Lilium. J Mol Biol 55: 357-378.

Inze D, De Veylder L. 2006. Cell cycle regulation in plant development. Annu Rev Genet 40: 77-105.

Ishibashi T, Kimura S, Sakaguchi K. 2006. A higher plant has three different types of RPA heterotrimeric complex. J Biochem 139: 99-104.

Iwata E, Ikeda S, Matsunaga S, Kurata M, Yoshioka Y, Criqui MC, Genschik P, Ito M. 2011. GIGAS CELL1, a novel negative regulator of the anaphase-promoting complex/cyclosome, is required for proper mitotic progression and cell fate determination in Arabidopsis. Plant Cell 23: 4382-4393.

* Jackson D, Wang X, Rudner DZ. 2013. Spatio-temporal organization of replication in bacteria and eukaryotes (nucleoids and nuclei). Cold Spring Harb Perspect Biol doi: 10.1101/cshperspect.a010389.

Jacob Y, Feng S, LeBlanc CA, Bernatavichute YV, Stroud H, Cokus S, Johnson LM, Pellegrini M, Jacobsen SE, Michaels SD. 2009. ATXR5 and ATXR6 are H3K27 monomethyltransferases required for chromatin structure and gene silencing. Nat Struct Mol Biol 16: 763-768.

Jacob Y, Stroud H, Leblanc C, Feng S, Zhuo L, Caro E, Hassel C, Gutierrez C, Michaels SD, Jacobsen SE. 2010. Regulation of heterochromatic DNA replication by histone H3 lysine 27 methyltransferases. Nature 466: 987991.

Jasencakova Z, Soppe WJ, Meister A, Gernand D, Turner BM, Schubert I. 2003. Histone modifications in Arabidopsis-high methylation of $\mathrm{H} 3$ lysine 9 is dispensable for constitutive heterochromatin. Plant J 33: 471-480.
Jenik PD, Jurkuta RE, Barton MK. 2005. Interactions between the cell cycle and embryonic patterning in Arabidopsis uncovered by a mutation in DNA polymerase epsilon. Plant Cell 17: 3362-3377.

Jeske H. 2009. Geminiviruses. Curr Top Microbiol Immunol 331: 185-226.

* Johansson E, Dixon N. 2013. Replicative DNA polymerases. Cold Spring Harb Perspect Biol doi: 10.1101/cshperspect.a012799.

Kanke M, Kodama Y, Takahashi TS, Nakagawa T, Masukata H. 2012. Mcm10 plays an essential role in origin DNA unwinding after loading of the CMG components. EMBO J 31: 2182-2194.

Kapoor A, Agarwal M, Andreucci A, Zheng X, Gong Z, Hasegawa PM, Bressan RA, Zhu JK. 2005. Mutations in a conserved replication protein suppress transcriptional gene silencing in a DNA-methylation-independent manner in Arabidopsis. Curr Biol 15: 1912-1918.

Karnani N, Taylor CM, Malhotra A, Dutta A. 2010. Genomic study of replication initiation in human chromosomes reveals the influence of transcription regulation and chromatin structure on origin selection. Mol Biol Cell 21: 393-404.

Kato K, Galis I, Suzuki S, Araki S, Demura T, Criqui MC, Potuschak T, Genschik P, Fukuda H, Matsuoka K, et al. 2009. Preferential up-regulation of G2/M phase-specific genes by overexpression of the hyperactive form of NtmybA2 lacking its negative regulation domain in tobacco BY-2 cells. Plant Physiol 149: 1945-1957.

Kessler B. 1971. Isolation, characterization and distribution of a DNA ligase from higher plants. Biochim Biophys Acta 240: 496-505.

Kimura S, Kai M, Kobayashi H, Suzuki A, Morioka H, Otsuka E, Sakaguchi K. 1997. A structure-specific endonuclease from cauliflower (Brassica oleracea var. botrytis) inflorescence. Nucleic Acids Res 25: 4970-4976.

Kimura S, Ueda T, Hatanaka M, Takenouchi M, Hashimoto J, Sakaguchi K. 2000. Plant homologue of flap endonuclease-1: Molecular cloning, characterization, and evidence of expression in meristematic tissues. Plant Mol Biol 42: 415-427.

Kimura S, Suzuki T, Yanagawa Y, Yamamoto T, Nakagawa H, Tanaka I, Hashimoto J, Sakaguchi K. 2001. Characterization of plant proliferating cell nuclear antigen (PCNA) and flap endonuclease-1 (FEN-1), and their distribution in mitotic and meiotic cell cycles. Plant J 28: 643-653.

Kimura S, Furukawa T, Kasai N, Mori Y, Kitamoto HK, Sugawara F, Hashimoto J, Sakaguchi K. 2003. Functional characterization of two flap endonuclease- 1 homologues in rice. Gene 314: 63-71.

Kodama H, Ito M, Ohnishi N, Suzuka I, Komamine A. 1991. Molecular cloning of the gene for plant proliferating-cell nuclear antigen and expression of this gene during the cell cycle in synchronized cultures of Catharanthus roseus cells. Eur J Biochem 197: 495-503.

Kong LJ, Hanley-Bowdoin L. 2002. A geminivirus replication protein interacts with a protein kinase and a motor protein that display different expression patterns during plant development and infection. Plant Cell 14: 18171832.

Kong LJ, Orozco BM, Roe JL, Nagar S, Ou S, Feiler HS, Durfee T, Miller AB, Gruissem W, Robertson D, et al. 
M. de la Paz Sanchez et al.

2000. A geminivirus replication protein interacts with the retinoblastoma protein through a novel domain to determine symptoms and tissue specificity of infection in plants. EMBO J 19: 3485-3495.

Kuo AJ, Song J, Cheung P, Ishibe-Murakami S, Yamazoe S, Chen JK, Patel DJ, Gozani O. 2012. The BAH domain of ORC1 links H4K20me2 to DNA replication licensing and Meier-Gorlin syndrome. Nature 484: 115-119.

Lai J, Chen H, Teng K, Zhao Q, Zhang Z, Li Y, Liang L, Xia R, Wu Y, Guo H, et al. 2009. RKP, a RING finger E3 ligase induced by BSCTV $\mathrm{C} 4$ protein, affects geminivirus infection by regulation of the plant cell cycle. Plant J 57: 905-917.

Lammens T, Boudolf V, Kheibarshekan L, Zalmas LP, Gaamouche T, Maes S, Vanstraelen M, Kondorosi E, La Thangue NB, Govaerts W, et al. 2008. Atypical E2F activity restrains APC/CCCS52A2 function obligatory for endocycle onset. Proc Natl Acad Sci 105: 14721-14726.

Laquel P, Castroviejo M, Litvak S. 1990. Further biochemical characterization of wheat DNA primase: Possible functional implication of copurification with DNA polymerase A. Nucleic Acids Res 18: 4867-4876.

Laquel P, Litvak S, Castroviejo M. 1993. Mammalian proliferating cell nuclear antigen stimulates the processivity of two wheat embryo DNA polymerases. Plant Physiol 102: $107-114$.

Larson-Rabin Z, Li Z, Masson PH, Day CD. 2009. FZR2/ CCS52A1 expression is a determinant of endoreduplication and cell expansion in Arabidopsis. Plant Physiol 149: 874-884.

Lee TJ, Pascuzzi PE, Settlage SB, Shultz RW, Tanurdzic M, Rabinowicz PD, Menges M, Zheng P, Main D, Murray JA, et al. 2010. Arabidopsis thaliana chromosome 4 replicates in two phases that correlate with chromatin state. PLoS Genet 6: e1000982.

* Leonard AC, Méchali M. 2013. DNA replication origins. Cold Spring Harb Perspect Biol doi: 10.1101/cshperspect.a010116.

Li ZY, Li B, Dong AW. 2012. The Arabidopsis transcription factor AtTCP15 regulates endoreduplication by modulating expression of key cell-cycle genes. Mol Plant 5: 270280.

Liu Q, Gong Z. 2011. The coupling of epigenome replication with DNA replication. Curr Opin Plant Biol 14: 187-194.

Liu J, Ren X, Yin H, Wang Y, Xia R, Wang Y, Gong Z. 2010a. Mutation in the catalytic subunit of DNA polymerase $\alpha$ influences transcriptional gene silencing and homologous recombination in Arabidopsis. Plant J 61: 36-45.

Liu Q, Wang J, Miki D, Xia R, Yu W, He J, Zheng Z, Zhu JK, Gong Z. 2010b. DNA replication factor C1 mediates genomic stability and transcriptional gene silencing in Arabidopsis. Plant Cell 22: 2336-2352.

Lopez I, Khan S, Vazquez-Ramos J, Hussey PJ. 1995. Molecular cloning of a maize cDNA clone encoding a putative proliferating cell nuclear antigen. Biochim Biophys Acta 1260: $119-121$.

Lozano-Duran R, Rosas-Diaz T, Luna AP, Bejarano ER. 2011. Identification of host genes involved in geminivirus infection using a reverse genetics approach. PLOS ONE 6: e22383.
Luque AE, Benedetto JP, Castroviejo M. 1998. Wheat DNA polymerase CI: A homologue of rat DNA polymerase $\beta$. Plant Mol Biol 38: 647-654.

Luque AE, Toueille M, Benedetto JP, Castroviejo M. 2000. Subunit composition of DNA polymerases A and B from wheat cell. Plant Physiol Biochem 38: 551-558.

Luque A, Sanz-Burgos AP, Ramirez-Parra E, Castellano MM, Gutierrez C. 2002. Interaction of geminivirus Rep protein with replication factor $\mathrm{C}$ and its potential role during geminivirus DNA replication. Virology 302: 83-94.

Lutzmann M, Grey C, Traver S, Ganier O, Maya-Mendoza A, Ranisavljevic N, Bernex F, Nishiyama A, Montel N, Gavois E, et al. 2012. MCM8- and MCM9-deficient mice reveal gametogenesis defects and genome instability due to impaired homologous recombination. Mol Cell 47: 523-534.

MacAlpine DM, Rodriguez HK, Bell SP. 2004. Coordination of replication and transcription along a Drosophila chromosome. Genes Dev 18: 3094-3105.

Macalpine HK, Gordan R, Powell SK, Hartemink AJ, Macalpine DM. 2010. Drosophila ORC localizes to open chromatin and marks sites of cohesin complex loading. Genome Res 20: 201-211.

Masuda HP, Ramos GB, de Almeida-Engler J, Cabral LM, Coqueiro VM, Macrini CM, Ferreira PC, Hemerly AS. 2004. Genome based identification and analysis of the pre-replicative complex of Arabidopsis thaliana. FEBS Lett 574: 192-202.

Masuda HP, Cabral LM, De Veylder L, Tanurdzic M, de Almeida Engler J, Geelen D, Inze D, Martienssen RA, Ferreira PC, Hemerly AS. 2008. ABAP1 is a novel plant Armadillo BTB protein involved in DNA replication and transcription. EMBO J 27: 2746-2756.

Mathieu O, Probst AV, Paszkowski J. 2005. Distinct regulation of histone $\mathrm{H} 3$ methylation at lysines 27 and 9 by $\mathrm{CpG}$ methylation in Arabidopsis. EMBO J 24: 2783-2791.

Matsumoto T, Hata S, Suzuka I, Hashimoto J. 1994. Expression of functional proliferating-cell nuclear antigen from rice (Oryza sativa) in Escherichia coli. Activity in association with human DNA polymerase $\delta$. Eur J Biochem 223: 179-187.

Mechali M. 2010. Eukaryotic DNA replication origins: Many choices for appropriate answers. Nat Rev 11: $728-738$.

Miotto B, Struhl K. 2010. HBO1 histone acetylase activity is essential for DNA replication licensing and inhibited by Geminin. Mol Cell 37: 57-66.

Moyer SE, Lewis PW, Botchan MR. 2006. Isolation of the Cdc45/Mcm2-7/GINS (CMG) complex, a candidate for the eukaryotic DNA replication fork helicase. Proc Natl Acad Sci 103: 10236-10241.

Nagar S, Hanley-Bowdoin L, Robertson D. 2002. Host DNA replication is induced by geminivirus infection of differentiated plant cells. Plant Cell 14: 2995-3007.

Nishimura K, Ishiai M, Horikawa K, Fukagawa T, Takata M, Takisawa H, Kanemaki MT. 2012. Mcm8 and Mcm9 form a complex that functions in homologous recombination repair induced by DNA interstrand crosslinks. Mol Cell 47: 511-522.

Nitta T, Nagata T. 1976. DNA fiber autoradiography of tobacco mesophyll protoplasts. Chromosoma 59: 83-88. 
Noguchi K, Vassilev A, Ghosh S, Yates JL, DePamphilis ML. 2006. The BAH domain facilitates the ability of human Orcl protein to activate replication origins in vivo. EMBO J 25: 5372-5382.

Park JA, Ahn JW, Kim YK, Kim SJ, Kim JK, Kim WT, Pai HS 2005. Retinoblastoma protein regulates cell proliferation, differentiation, and endoreduplication in plants. Plant $J$ 42: $153-163$.

Pilartz M, Jeske H. 1992. Abutilon mosaic geminivirus double-stranded DNA is packed into minichromosomes. $\mathrm{Vi}$ rology 189: 800-802.

Przykorska A, Solecka K, Olszak K, Keith G, Nawrot B, Kuligowska E. 2004. Wheat (Triticum vulgare) chloroplast nuclease ChSI exhibits $5^{\prime}$ flap structure-specific endonuclease activity. Biochemistry 43: 11283-11294.

Ramirez-Parra E, Gutierrez C. 2007a. E2F regulates FASCIATA1, a chromatin assembly gene whose loss switches on the endocycle and activates gene expression by changing the epigenetic status. Plant Physiol 144: 105-120.

Ramirez-Parra E, Gutierrez C. 2007b. The many faces of chromatin assembly factor 1 . Trends Plant Sci 12: 570576.

Ramirez-Parra E, del Pozo JC, Desvoyes B, Sanchez MP, Gutierrez C. 2007. E2F-DP transcription factors. In Cell cycle control and plant development (ed. Inzé D), pp. 138-162. Blackwell, Oxford.

Raynaud C, Sozzani R, Glab N, Domenichini S, Perennes C, Cella R, Kondorosi E, Bergounioux C. 2006. Two cellcycle regulated SET-domain proteins interact with proliferating cell nuclear antigen (PCNA) in Arabidopsis. Plant J 47: 395-407.

Richard MC, Litvak S, Castroviejo M. 1991. DNA polymerase B from wheat embryos: A plant $\delta$-like DNA polymerase. Arch Biochem Biophys 287: 141-150.

Ronceret A, Guilleminot J, Lincker F, Gadea-Vacas J, Delorme V, Bechtold N, Pelletier G, Delseny M, Chaboute ME, Devic M. 2005. Genetic analysis of two Arabidopsis DNA polymerase epsilon subunits during early embryogenesis. Plant J 44: 223-236.

Roudier F, Ahmed I, Berard C, Sarazin A, Mary-Huard T, Cortijo S, Bouyer D, Caillieux E, Duvernois-Berthet E, Al-Shikhley L, et al. 2011. Integrative epigenomic mapping defines four main chromatin states in Arabidopsis. EMBO J 30: 1928-1938.

Rufiange A, Jacques PE, Bhat W, Robert F, Nourani A. 2007. Genome-wide replication-independent histone H3 exchange occurs predominantly at promoters and implicates H3 K56 acetylation and Asf1. Mol Cell 27: 393-405.

Sabelli PA, Burgess SR, Kush AK, Young MR, Shewry PR. 1996. cDNA cloning and characterisation of a maize homologue of the MCM proteins required for the initiation of DNA replication. Mol Gen Genet 252: 125-136.

Sabelli PA, Burgess SR, Valasek L, Shewry PR. 1999. Molecular cloning and characterisation of a maize cDNA for a homologue of the large subunit of the eukaryotic initiation factor 3 (eIF3). Mol Gen Genet 261: 820-830.

Sakaguchi K, Ishibashi T, Uchiyama Y, Iwabata K. 2009. The multi-replication protein A (RPA) system-a new perspective. FEBS J 276: 943-963.
Sanchez MP, Gutierrez C. 2009. Arabidopsis ORC1 is a PHDcontaining H3K4me3 effector that regulates transcription. Proc Natl Acad Sci 106: 2065-2070.

Sanchez MP, Torres A, Boniotti MB, Gutierrez C, VazquezRamo JM. 2002. PCNA protein associates to Cdk-A type protein kinases in germinating maize. Plant Mol Biol 50: $167-175$.

Sanchez MP, Gurusinghe SH, Bradford KJ, VazquezRamos JM. 2005. Differential response of PCNA and Cdk-A proteins and associated kinase activities to benzyladenine and abscisic acid during maize seed germination. J Exp Bot 56: 515-523.

Sanchez-Duran MA, Dallas MB, Ascencio-Ibanez JT, Reyes MI, Arroyo-Mateos M, Ruiz-Albert J, HanleyBowdoin L, Bejarano ER. 2011. Interaction between geminivirus replication protein and the SUMO-conjugating enzyme is required for viral infection. J Virol 85: 97899800.

Sasaki T, Gilbert DM. 2007. The many faces of the origin recognition complex. Curr Opin Cell Biol 19: 337-343.

Saunders K. 2008. Analysis of geminivirus DNA replication by 2-D gel. Methods Mol Biol 51: 135-143.

Schmid M, Davison TS, Henz SR, Pape UJ, Demar M, Vingron M, Scholkopf B, Weigel D, Lohmann JU. 2005. A gene expression map of Arabidopsis thaliana development. Nat Genet 37: 501-506.

Schwaiger M, Stadler MB, Bell O, Kohler H, Oakeley EJ, Schubeler D. 2009. Chromatin state marks cell-typeand gender-specific replication of the Drosophila genome. Genes Dev 23: 589-601.

Selth LA, Dogra SC, Rasheed MS, Healy H, Randles JW, Rezaian MA. 2005. A NAC domain protein interacts with tomato leaf curl virus replication accessory protein and enhances viral replication. Plant Cell 17: 311-325.

Shimizu S, Mori H. 1998. Analysis of cycles of dormancy and growth in pea axillary buds based on mRNA accumulation patterns of cell cycle-related genes. Plant Cell Physiol 39: 255-262.

Shultz RW, Tatineni VM, Hanley-Bowdoin L, Thompson WF. 2007. Genome-wide analysis of the core DNA replication machinery in the higher plants Arabidopsis and rice. Plant Physiol 144: 1697-1714.

Shultz RW, Lee TJ, Allen GC, Thompson WF, HanleyBowdoin L. 2009. Dynamic localization of the DNA replication proteins MCM5 and MCM7 in plants. Plant Physiol 150: 658-669.

Singh DK, Islam MN, Choudhury NR, Karjee S, Mukherjee SK. 2007. The $32 \mathrm{kDa}$ subunit of replication protein A (RPA) participates in the DNA replication of Mung bean yellow mosaic India virus (MYMIV) by interacting with the viral Rep protein. Nucleic Acids Res 35: 755-770.

Stevens R, Mariconti L, Rossignol P, Perennes C, Cella R, Bergounioux C. 2002. Two E2F sites in the Arabidopsis MCM3 promoter have different roles in cell cycle activation and meristematic expression. J Biol Chem 277: 32978-32984.

Stevens R, Grelon M, Vezon D, Oh J, Meyer P, Perennes C, Domenichini S, Bergounioux C. 2004. A CDC45 homo$\log$ in Arabidopsis is essential for meiosis, as shown by RNA interference-induced gene silencing. Plant Cell 16: 99-113. 
M. de la Paz Sanchez et al.

Stroud H, Hale CJ, Feng S, Caro E, Jacob Y, Michaels SD, Jacobsen SE. 2012a. DNA methyltransferases are required to induce heterochromatic re-replication in Arabidopsis. PLoS Genet 8: e1002808.

Stroud H, Otero S, Desvoyes B, Ramírez-Parra E, Jacobsen SE, Gutierrez C. 2012b. Genome-wide analysis of histone H3.1 and H3.3 variants in Arabidopsis thaliana. Proc Natl Acad Sci 109: 5379-5375.

Strzalka W, Oyama T, Tori K, Morikawa K. 2009. Crystal structures of the Arabidopsis thaliana proliferating cell nuclear antigen 1 and 2 proteins complexed with the human p21 C-terminal segment. Protein Sci 18: 10721080.

Strzalka W, Kaczmarek A, Naganowska B, Ziemienowicz A. 2010. Identification and functional analysis of PCNA1 and PCNA-likel genes of Phaseolus coccineus. J Exp Bot 61: $873-888$.

Sugimoto-Shirasu K, Stacey NJ, Corsar J, Roberts K, McCann MC. 2002. DNA topoisomerase VI is essential for endoreduplication in Arabidopsis. Curr Biol 12: $1782-1786$.

Sugimoto-Shirasu K, Roberts GR, Stacey NJ, McCann MC, Maxwell A, Roberts K. 2005. RHL1 is an essential component of the plant DNA topoisomerase VI complex and is required for ploidy-dependent cell growth. Proc Nat Acad Sci 102: 18736-18741.

Suzuka I, Daidoji H, Matsuoka M, Kadowaki K, Takasaki Y, Nakane PK, Moriuchi T. 1989. Gene for proliferating-cell nuclear antigen (DNA polymerase $\delta$ auxiliary protein) is present in both mammalian and higher plant genomes. Proc Natl Acad Sci 86: 3189-3193.

Takahashi N, Lammens T, Boudolf V, Maes S, Yoshizumi T, De Jaeger G, Witters E, Inze D, De Veylder L. 2008. The DNA replication checkpoint aids survival of plants deficient in the novel replisome factor ETG1. EMBO J 27: $1840-1851$.

Takahashi N, Quimbaya M, Schubert V, Lammens T, Vandepoele K, Schubert I, Matsui M, Inze D, Berx G, De Veylder L. 2010. The MCM-binding protein ETG1 aids sister chromatid cohesion required for postreplicative homologous recombination repair. PLoS Genet 6: e1000817.

Tardat M, Brustel J, Kirsh O, Lefevbre C, Callanan M, Sardet C, Julien E. 2010. The histone H4 Lys 20 methyltransferase PR-Set7 regulates replication origins in mammalian cells. Nat Cell Biol 12: 1086-1093.

Taylor JH, Woods PS, Hughes WL. 1957. The organization and duplication of chromosomes as revealed by autoradiographic studies using tritium-labeled Thymidinee. Proc Natl Acad Sci 43: 122-128.

Taylor RM, Hamer MJ, Rosamond J, Bray CM. 1998. Molecular cloning and functional analysis of the Arabidopsis thaliana DNA ligase I homologue. Plant J 14: 75-81.

Uchiyama Y, Hatanaka M, Kimura S, Ishibashi T, Ueda T, Sakakibara Y, Matsumoto T, Furukawa T, Hashimoto J, Sakaguchi K. 2002. Characterization of DNA polymerase $\delta$ from a higher plant, rice (Oryza sativa L.). Gene 295: $19-26$.

Valenzuela MS, Chen Y, Davis S, Yang F, Walker RL, Bilke S, Lueders J, Martin MM, Aladjem MI, Massion PP, et al. 2011. Preferential localization of human origins of DNA replication at the $5^{\prime}$-ends of expressed genes and at evo- lutionarily conserved DNA sequences. PLoS ONE 6: e17308.

van Deursen F, Sengupta S, De Piccoli G, Sanchez-Diaz A, Labib K. 2012. Mcm10 associates with the loaded DNA helicase at replication origins and defines a novel step in its activation. EMBO J 31: 2195-2206.

Vanitharani R, Chellappan P, Fauquet CM. 2005. Geminiviruses and RNA silencing. Trends Plant Sci 10: 144-151.

Van't Hof J. 1976. Replicon size and rate of fork movement in early S of higher plant cells (Pisum sativum). Exp Cell Res 103: 395-403.

Van't Hof J, Bjerknes CA. 1981. Similar replicon properties of higher plant cells with different $\mathrm{S}$ periods and genome sizes. Exp Cell Res 136: 461-465.

Van't Hof J, Lamm SS. 1992. Site of initiation of replication of the ribosomal genes of pea (Pisum sativum) detected by two-dimensional gel electrophoresis. Plant Mol Biol 20: 377-382.

Van't Hof J, Kuniyuki A, Bjerknes CA. 1978. The size and number of replicon families of chromosomal DNA of Arabidopsis thaliana. Chromosoma 68: 269-285.

Van't Hof J, Hernandez P, Bjerknes CA, Lamm SS. 1987. Location of the replication origin in the $9 \mathrm{~kb}$ repeat size class of rDNA in pea (Pisum sativum). Plant Mol Biol 9: 87-96.

Verkest A, Manes CL, Vercruysse S, Maes S, Van Der Schueren E, Beeckman T, Genschik P, Kuiper M, Inze D, De Veylder L. 2005. The cyclin-dependent kinase inhibitor KRP2 controls the onset of the endoreduplication cycle during Arabidopsis leaf development through inhibition of mitotic CDKA;1 kinase complexes. Plant Cell 17: 1723-1736.

Walker JD, Oppenheimer DG, Concienne J, Larkin JC. 2000. SIAMESE, a gene controlling the endoreduplication cell cycle in Arabidopsis thaliana trichomes. Development 127: 3931-3940.

Wang H, Zhou Y, Gilmer S, Whitwill S, Fowke LC. 2000. Expression of the plant cyclin-dependent kinase inhibitor ICK1 affects cell division, plant growth and morphology. Plant J 24: 613-623.

Watase G, Takisawa H, Kanemaki MT. 2012. Mcm10 plays a role in functioning of the eukaryotic replicative DNA helicase, Cdc45-Mcm-GINS. Curr Biol 22: 343-349.

Weinl C, Marquardt S, Kuijt SJ, Nowack MK, Jakoby MJ, Hulskamp M, Schnittger A. 2005. Novel functions of plant cyclin-dependent kinase inhibitors, ICK1/KRP1, can act non-cell-autonomously and inhibit entry into mitosis. Plant Cell 17: 1704-1722.

Witmer X, Alvarez-Venegas R, San-Miguel P, Danilevskaya O, Avramova Z. 2003. Putative subunits of the maize origin of replication recognition complex ZmORC1ZmORC5. Nucleic Acids Res 31: 619-628.

Xia R, Wang J, Liu C, Wang Y, Wang Y, Zhai J, Liu J, Hong X, Cao X, Zhu JK, et al. 2006. ROR1/RPA2A, a putative replication protein $\mathrm{A} 2$, functions in epigenetic gene silencing and in regulation of meristem development in Arabidopsis. Plant Cell 18: 85-103.

Xie Q, Suarez-Lopez P, Gutierrez C. 1995. Identification and analysis of a retinoblastoma binding motif in the replication protein of a plant DNA virus: Requirement for efficient viral DNA replication. EMBO J 14: 4073-4082. 
Xie Q, Sanz-Burgos AP, Guo H, Garcia JA, Gutierrez C. 1999. GRAB proteins, novel members of the NAC domain family, isolated by their interaction with a geminivirus protein. Plant Mol Biol 39: 647-656.

Yin $\mathrm{H}$, Zhang $\mathrm{X}$, Liu J, Wang Y, He J, Yang T, Hong X, Yang Q, Gong Z. 2009. Epigenetic regulation, somatic homologous recombination, and abscisic acid signaling are influenced by DNA polymerase epsilon mutation in Arabidopsis. Plant Cell 21: 386-402.

Yoshizumi T, Tsumoto Y, Takiguchi T, Nagata N, Yamamoto YY, Kawashima M, Ichikawa T, Nakazawa M, Yamamoto N, et al. 2006. Increased level of polyploidy1, a conserved repressor of CYCLINA2 transcription, con- trols endoreduplication in Arabidopsis. Plant Cell 18: $2452-2468$.

Zhang K, Sridhar VV, Zhu J, Kapoor A, Zhu JK. 2007. Distinctive core histone post-translational modification patterns in Arabidopsis thaliana. PLoS ONE 2: e1210.

Zhang Z, Chen H, Huang X, Xia R, Zhao Q, Lai J, Teng K, Li Y, Liang L, Du Q, et al. 2011. BSCTV C2 attenuates the degradation of SAMDC1 to suppress DNA methylationmediated gene silencing in Arabidopsis. Plant Cell 23: 273-288.

* Zielke N, Edgar BA, DePamphilis ML. 2013. Endoreplication. Cold Spring Harb Perspect Biol doi: 10.1101/cshperspect.a012948. 


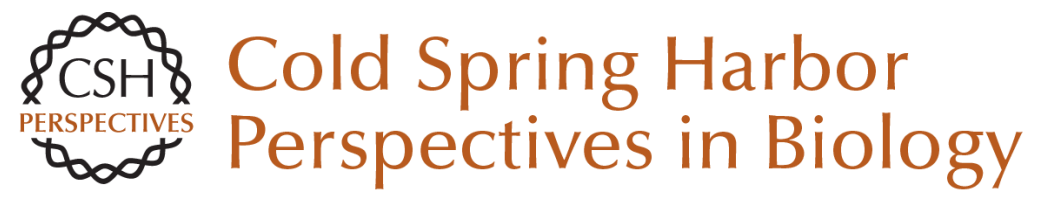

\section{Regulating DNA Replication in Plants}

Maria de la Paz Sanchez, Celina Costas, Joana Sequeira-Mendes and Crisanto Gutierrez

Cold Spring Harb Perspect Biol 2012; doi: 10.1101/cshperspect.a010140

\section{Subject Collection DNA Replication}

\section{Replication of Epstein-Barr Viral DNA} Wolfgang Hammerschmidt and Bill Sugden

Replication Proteins and Human Disease Andrew P. Jackson, Ronald A. Laskey and Nicholas Coleman

Break-Induced DNA Replication Ranjith P. Anand, Susan T. Lovett and James E. Haber

Regulating DNA Replication in Eukarya Khalid Siddiqui, Kin Fan On and John F.X. Diffley

Archaeology of Eukaryotic DNA Replication Kira S. Makarova and Eugene V. Koonin

Translesion DNA Polymerases Myron F. Goodman and Roger Woodgate

Human Papillomavirus Infections: Warts or Cancer?

Louise T. Chow and Thomas R. Broker

\section{Chromatin and DNA Replication}

David M. MacAlpine and Geneviève Almouzni
Endoreplication
Norman Zielke, Bruce A. Edgar and Melvin L. DePamphilis
Replication-Fork Dynamics
Karl E. Duderstadt, Rodrigo Reyes-Lamothe, Antoine M. van Oijen, et al.
Helicase Activation and Establishment of Replication Forks at Chromosomal Origins of Replication Seiji Tanaka and Hiroyuki Araki
Poxvirus DNA Replication Bernard Moss

The Minichromosome Maintenance Replicative Helicase

Stephen D. Bell and Michael R. Botchan

DNA Replication Origins Alan C. Leonard and Marcel Méchali

Principles and Concepts of DNA Replication in

Bacteria, Archaea, and Eukarya

Michael O'Donnell, Lance Langston and Bruce Stillman

DNA Replication Timing

Nicholas Rhind and David M. Gilbert

For additional articles in this collection, see http://cshperspectives.cshlp.org/cgi/collection/

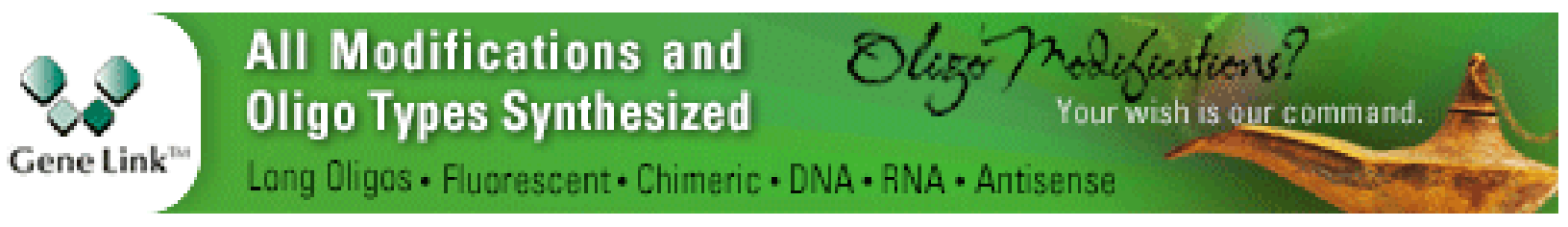

Copyright @ 2012 Cold Spring Harbor Laboratory Press; all rights reserved 